\title{
TGF-B AS A MARKER OF ULCERATIVE COLITIS AND DISEASE SEVERITY
}

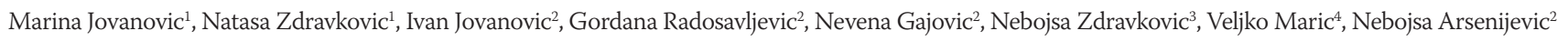 \\ ${ }^{1}$ Department of Internal medicine, Faculty of Medical Sciences, University of Kragujevac, Serbia \\ ${ }^{2}$ Center for Molecular Medicine and Stem Cell Research, Faculty of Medical Sciences, University of Kragujevac, Serbia \\ ${ }^{3}$ Department of Medical informatics and statistics, Faculty of Medical Sciences, University of Kragujevac, Serbia \\ ${ }^{4}$ Department of Surgery, Faculty of Medicine Foca, University of East Sarajevo, Bosnia and Herzegovina

\section{TGF-B KAO MARKER ULCEROZNOG KOLITISA I TEŽINE BOLESTI}

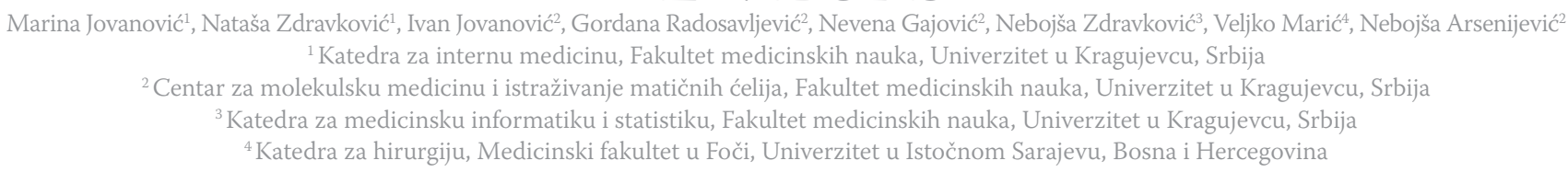

\section{ABSTRACT}

Ulcerative colitis $(U C)$ represents chronic inflammation of the large intestine. Immune response plays an important role in disease genesis and progression. Activated leukocytes secrete several cytokines that actively regulate the inflammatory response in UC. The aim of this study was to determine levels of cytokines IL-17, IL-27, IFN- $\gamma$ and TGF- $\beta$ in patients with $U C$ and to test them as biomarkers for disease.

The blood samples of 24 patients with ulcerative colitis without previous treatment and 37 healthy individuals were analyzed. Serum levels of $I L-17, I L-27, I F N-\gamma$ and TGF- $\beta$ were measured using sensitive enzyme-linked immunosorbent assay (ELISA) kits.

Serum levels of IL-17, IL-27, IFN- $\gamma$ and TGF- $\beta$ were increased in patients with $U C$, compared to healthy controls ( $p=0.022$; $p=0.001 ; p=0.001$; and $p=0.002$; respectively). Ratios of cytokines IL-27/IL-17, IFN- $\gamma /$ TGF- $\beta$ and IL-17/TGF- $\beta$ were significantly higher in group of patients with $U C(p=0.002 ; p=0.002 ; p=0.003$; respectively). Serum value of TGF- $\beta$ higher than $20 \mathrm{pg} / \mathrm{ml}$ presents a highly sensitive and specific marker for $U C$.

We believe that increased production and predominance of immunosupressive TGF- $\beta$ may represent compensatory mechanism for ongoing pro-inflammatory processes in UC.

Keywords: Ulcerative colitis, IL-17, IL-27, IFN- $\gamma$ and TGF- $\beta$

\section{SAŽETAK}

Ulcerozni kolitis je hronično inflamacijsko oboljenje debelog creva. Imunski odgovor igra važnu ulogu u nastanku i progresiji bolesti. Aktivirani leukociti sekretuju brojne citokine koji modulišu inflamacijski odgovor u ulceroznom kolitisu. Cilj ove studije je odredivanje nivoa citokina IL-17, IL27, IFN-y $i$ TGF- $\beta$ i njihove specifičnosti $i$ senzitivnosti kao biomarkera bolesti kod pacijenata sa ulceroznim kolitisom.

Analizirani su uzorci krvi 24 pacijenata obolelih od ulceroznog kolitisa i 37 zdravih kontrola. Serumski nivoi IL-17, IL-27, IFN- $\gamma$ i TGF- $\beta$ su mereni ELISA testom.

Serumski nivoi IL-17, IL-27, IFN-y i TGF- $\beta$ su povišeni kod pacijenata obolelih od ulceroznog kolitisa u poređenju sa kontrolnom grupom ( $p=0.022 ; p=0.001 ; p=0.001 ; p=0.002)$. Odnos IL-27/IL-17, IFN- $\gamma /$ TGF- $\beta$ i IL-17/TGF- $\beta$ je značajno veći u grupi pacijenata sa ulceroznim kolitisom ( $p=0.002$; $p=0.002 ; p=0.003)$. Serumska vrednost TGF- $\beta$ veća od 20 pg/ ml predstavlja visoko senzitivan i specifičan marker za potvrdu ulceroznog kolitisa.

Smatramo da povećana produkcija imunosupresivnog TGF- $\beta$ može predstavljati mehanizam kompenzovanja proinflamacijskog procesa u ulceroznom kolitisu.

Ključne reči: Ulcerozni kolitis, IL-17, IL-27, IFN- $\gamma$ i TGF- $\beta$

\section{INTRODUCTION}

Inflammatory bowel disease (IBD) represents a group of chronic disorders. It includes Crohn's disease (CD) and ulcerative colitis (UC). Main characteristics of disease are chronic inflammation of the gastrointestinal tract and relapsing and remitting clinical course (1). Ulcerative colitis (UC) represents chronic inflammation of the large intestine still with unknown etiology. The disease genesis in- volves the breakdown of intestinal mucosal homeostasis and subsequent pathological communication between commensal microflora and local immune system which is followed by inadequate immune response (2). Immune response plays a critical role during disease progression. Activated leukocytes secrete several cytokines that actively regulate the inflammatory response in UC (1). 
Cytokines represent a group of various small proteins, secreted by cells and playing crucial role in intercellular signaling and communication. They are involved in various biological process such as embryonic development, disease pathogenesis, non-specific response to infection, specific response to antigen, changes in cognitive functions and progression of the degenerative processes of aging, stem cell differentiation, vaccine efficacy and allograft rejection $(3,4)$.

IFN- $\gamma$ is an immunoregulatory cytokine involved in the regulation of many phases of the immune and inflammatory responses, including the activation and differentiation of various leukocytes (5). Cellular effects of IFN- $\gamma$ include up-regulation of pathogen recognition, antigen processing and presentation, the antiviral state, inhibition of cellular proliferation and effects on apoptosis, activation of microbicidal effector functions, immunomodulation and leukocyte trafficking. $\mathrm{CD} 8^{+} \mathrm{T}$ cells, $\mathrm{CD} 4^{+} \mathrm{Th}$ cells and NK cells represent main sources of IFN- $\gamma$ (6). IFN- $\gamma$ secretion is a hallmark of Th1 lymphocytes and facilitates type 1 immune response, critical for defense against certain pathogen, such as intracellular bacteria, viruses and fungi $(5,6)$.

The interleukin-17 (IL-17) family consists of a subset of cytokines. The most widely investigated member of this family is IL-17A. Beside Th17 cells, a major source of this cytokine, innate immune cell also produce IL-17A, in response to pathogens or tissue injury (7-9). The interleukin-17 family participates in both acute and chronic inflammatory responses (10-19). IL-17 elicits protection against extracellular bacterial and fungal infections and plays important roles in biology of various inflammatory conditions such as autoimmune diseases, metabolic disorders, and cancer (10-19).

IL-27 is a member of a family of cytokines, which also includes IL-12, IL-23, and IL-35 $(20,21)$. IL-27 is mainly produced by cells of myeloid origin such as monocytes, macrophages, dendritic cells, and microglial cells, in response to stimuli acting through Toll-like receptors or TNFR-family members $(22,23)$. It is produced during the innate phase of the immune response and regulates the quality and size of the adaptive immune response $(24,25)$.

Transforming Growth Factor $\beta$ (TGF- $\beta$ ) is a powerful pleiotropic cytokine, with predominantly immune-suppressing and anti-inflammatory properties. Under physiological conditions, TGF- $\beta$ has a role in embryogenesis, cell proliferation, differentiation, apoptosis, adhesion, and invasion $(26,27)$.

The aim of present study was to assess the serum level of cytokines IL-17, IL-27, IFN- $\gamma$ and TGF- $\beta$ in patients with UC and to test them as biomarkers for disease. The results showed increased systemic values of cytokines IL17, IL-27, IFN- $\gamma$ and TGF- $\beta$ and revealed TGF- $\beta$ highly sensitive and specific marker for UC.

\section{MATERIALS AND METHODS}

\section{Ethical approvals}

The study was conducted at the Center for Gastroenterology, University Medical Center Kragujevac, Serbia and the Center for Molecular Medicine and Stem Cell Research, Faculty of Medical Sciences, University of Kragujevac, Serbia. Ethical approvals were obtained from relevant Ethics Committees of Faculty of Medical Sciences, University of Kragujevac, Serbia and University Medical Center, Kragujevac, Serbia. All research procedures were made to the Principle of Good Clinical Practice and the Declaration of Helsinki at all times.

\section{Patients}

The study included total of 24 patients with ulcerative colitis (13 males and 11 females; mean age: $45.74 \pm 19.00$ years). Ulcerative colitis was diagnosed on the basis of endoscopic and histopathological criteria. The study did not involve patients with ulcerative colitis who were previously treated with antibiotics, aminosalicylates, corticosteroids, immunosuppressive agents, and biological therapy. All subjects had a complete medical history, including physical examination, routine laboratory tests and diagnostic imaging (chest X-ray, abdominal ultrasound, abdominal computed tomography scan and endoscopy). Control subjects were selected from volunteer blood donors at the University Medical Center Kragujevac. A control group of 37 healthy individuals was matched with the experimental group based on gender.

\section{Measurement of cytokines in the serum}

The blood samples of all patients were collected before any application of therapy. Blood samples were collected from each studied subject. Blood clot was cut and centrifuged for serum separation. All serum samples were stored at $-20^{\circ} \mathrm{C}$ until the time of testing. Repeated freeze-thaw cycles were avoided to prevent loss of bioactive substances. Serum levels of cytokines were measured as described before (28), using sensitive enzyme-linked immunosorbent assay (ELISA) kits (R\&D Systems Minneapolis, MN, USA for IL-17, IL-27, IFN- $\gamma$ and TGF- $\beta$ ), specific for human cytokines, according to the manufacturer's instructions. The optical density of each well at $450 \mathrm{~nm}$ was detected by an ELISA microplate reader (Zenyth, 3100).

\section{Statistical analysis}

The statistical analyses were performed using SPSS 20.0 software. Data are grouped and shown in graphs. The normality of distribution was tested by Kolmogorov-Smirnov test. Statistical differences between the means for the different groups were evaluated using either the two-tailed Student's t test or nonparametric Mann-Whitney U test where appropriate. ROC curve was used for the review of sensitivity and specificity. All reported $\mathrm{P}$ values were 2 -sided and the results were considered significantly different when $p$ $<0.05$ and highly significantly different when $\mathrm{p}<0.01$. 

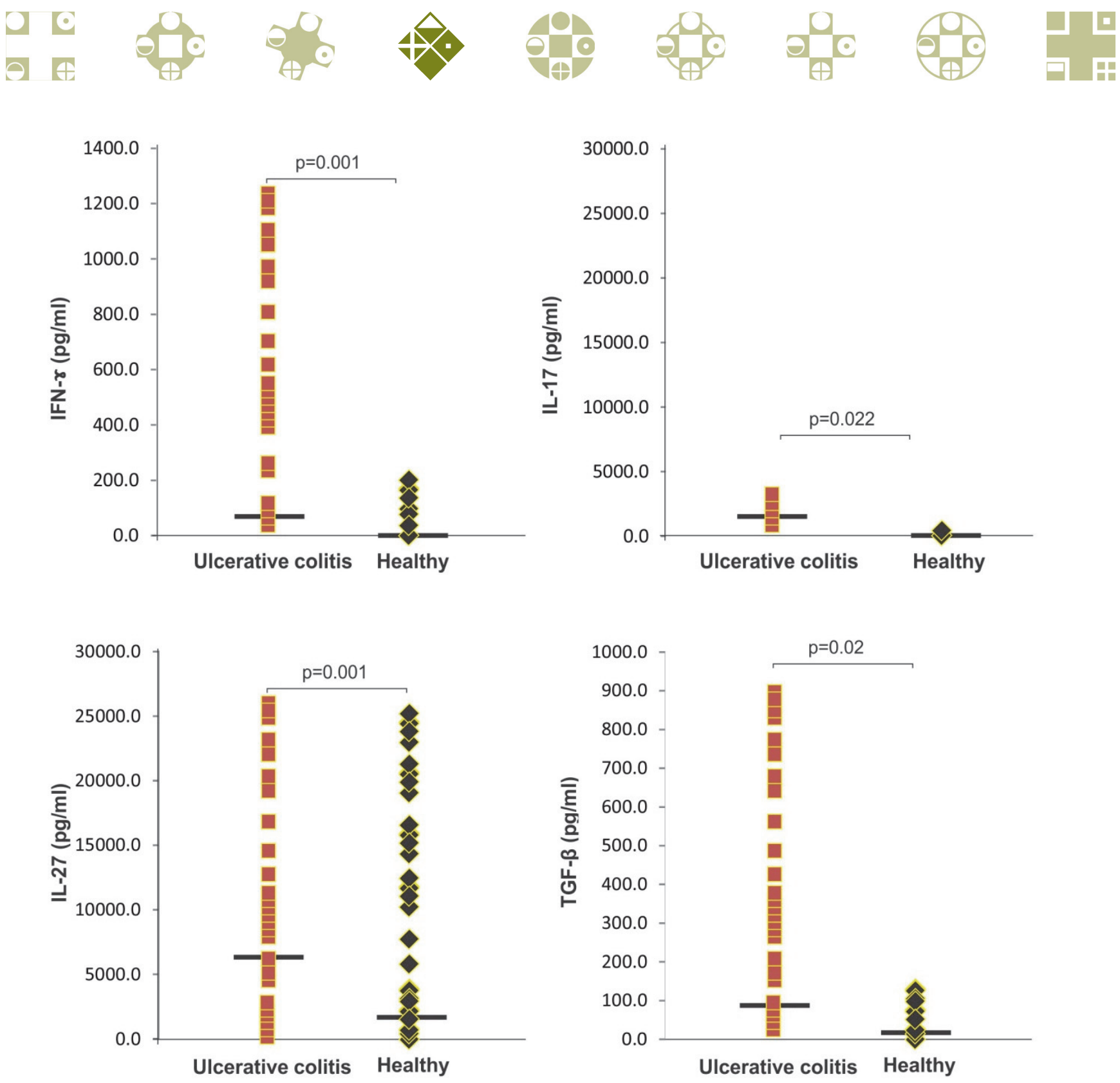

Figure 1. Serum values of IL-17, IL-27, IFN- $\gamma$ and TGF- $\beta$ in patients with UC. Increased concentration of IL-17, IL-27, IFN- $\gamma$ and TGF- $\beta$ in patients with UC in comparison to healthy control. Serum levels of all mentioned cytokines were determined by ELISA. Statistical significance was tested by

\section{RESULTS}

Sera of patients with UC contain higher levels of IL-17, IL-27, IFN- $\gamma$ and TGF- $\beta$

We have compared serum concentrations of cytokines in groups of patients with UC and healthy controls. Serum levels of IL-17, IL-27, IFN- $\gamma$ and TGF- $\beta$ were significantly increased in patients with $\mathrm{UC}$ in comparison to healthy controls (IL-17: 32,20 (0,00-4021,30) vs. 0,00 (0,00316,50) pg/ml, p=0.022; IL-27: 6332,60 (914,00-71038,50) vs. $1832,68(0,00-26094,90) \mathrm{pg} / \mathrm{ml}, \mathrm{p}=0.001$; IFN- $\gamma: 71,70$ $(7,30-1274,90)$ vs. $0,00 \quad(0,00-219,60) \quad \mathrm{pg} / \mathrm{ml}, \mathrm{p}=0.001$; TGF- $\beta$ : $92,20(4,93-933,80)$ vs. $17,70(0,00-110,60) \mathrm{pg} / \mathrm{ml}$, $\mathrm{p}=0.002$; Figure 1).

\section{IL-27/IL-17, IFN- $\gamma /$ TGF- $\beta$ and IL-17/TGF- $\beta$} ratios were altered in patients with $\mathrm{UC}$

It has been suggested that ratio of counterregulatory cytokines is a relevant marker of the disease process. Therefore, we considered ratios of pro- and anti-inflammatory cytokines studied. The significant difference was found for IL-27/IL-17, IFN- $\gamma /$ TGF- $\beta$ and IL-17/TGF- $\beta$ ratio. IL-27/IL-17, IFN- $\gamma /$ TGF- $\beta$ and IL-17/TGF- $\beta$ ratio was increased in patients with UC, comparing to healthy volunteers (IL-27/IL-17: 116,67 $(0,00-679,69)$ vs. $0,00(0,00-5895,44), \mathrm{p}=0.002 ;$ IFN- $\gamma /$ TGF- $\beta$ : $0,82(0,03-16,77)$ vs. $0,00(0,00-3,76), \mathrm{p}=0.002$; IL-17/TGF- $\beta$ : $0,47(0,00-34,89)$ vs. $0,00(0,00-21.65), \mathrm{p}=0.003$; Figure 2$)$. 

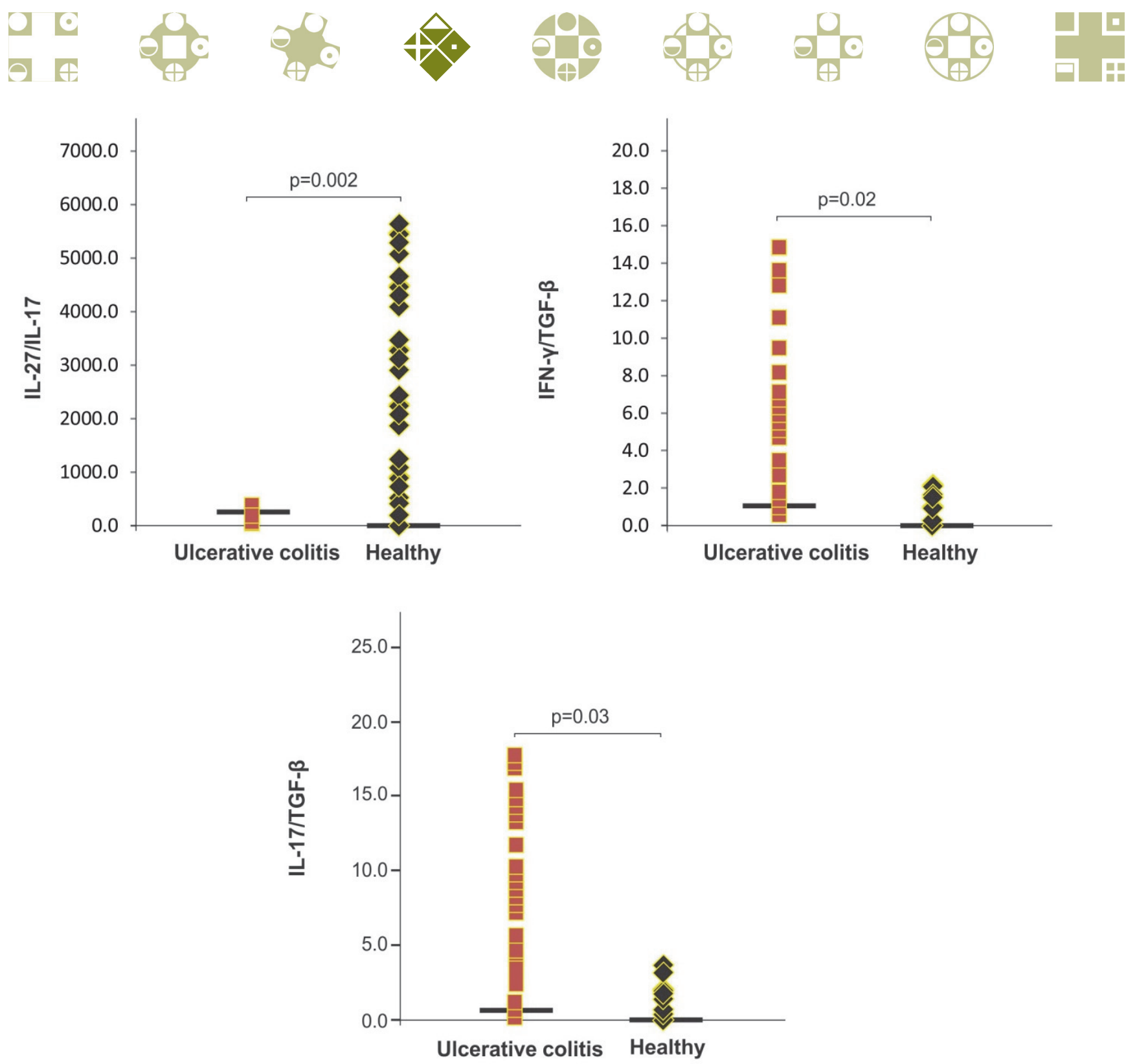

Figure 2. IL-27/IL-17, IFN- $\gamma /$ TGF- $\beta$ and IL-17/TGF- $\beta$ ratios in patients with UC. Increased IL-27/IL-17, IFN- $\gamma /$ TGF- $\beta$ and IL-17/TGF- $\beta$ ratios in patients with UC in comparison to healthy control. Serum levels of all mentioned cytokines were determined by ELISA. Statistical significance was tested by Mann-Whitney Rank Sum test or independent samples t-test, where appropriate.

\section{Logistic regression analyses of IL-17, IL-27, IFN- $\gamma$ and TGF- $\beta$ serum level in patients with UC and healthy controls}

Binary logistic regression showed that higher serum levels of IL-17, IL-27, IFN- $\gamma$ and TGF- $\beta$ strongly correlated with presence of UC (IL-17: sensitivity $85,2 \%$, specificity $71,4 \%$, cut-off $=20 \mathrm{pg} / \mathrm{ml} ; \mathrm{p}=0.032$; IL-27: sensitivity $74,1 \%$, specificity $80,0 \%$, cut-off $=1000 \mathrm{pg} /$ $\mathrm{ml} ; \mathrm{p}=0.006$; IFN- $\gamma$ : sensitivity $100,0 \%$, specificity $68,6 \%$, cut-off $=53 \mathrm{pg} / \mathrm{ml} ; \mathrm{p}=0.002$; TGF- $\beta$ : sensitivity $85,2 \%$, specificity $88,6 \%$, cut-off $=20 \mathrm{pg} / \mathrm{ml} ; \mathrm{p}=0.001$; Figure 3 ). TGF- $\beta$ can be a valuable marker for distinguishing patients with UC from healthy control. The optimal cutoff value estimated for TGF- $\beta$ that allows the discrimination was $20 \mathrm{pg} / \mathrm{ml}$.

\section{Serum concentration of TGF- $\beta$ was altered in UC patients with different disease severity}

Patients with UC were categorized in two groups based on presence of extraintestinal manifestations (dermatologic manifestations- pyoderma gangrenosum or erythema nodosum) (29). We analyzed serum level of TGF- $\beta$ in defined groups. Serum concentration of TGF- $\beta$ was higher in group of patients with notable extraintestinal manifestations, although this difference did not reach statistical significance (TGF- $\beta$ : 113,66 (4,39-157,81) vs. 78,08 (11,62$323,41) \mathrm{pg} / \mathrm{ml}$; Figure 4). Further, we divided patients in another two categories: patients with detectable and patients without detectable local complications (stricture and pseudopolyposis) $(30,31)$ and analyzed them for systemic value of TGF- $\beta$. We found increment of TGF- $\beta$ in pres- 

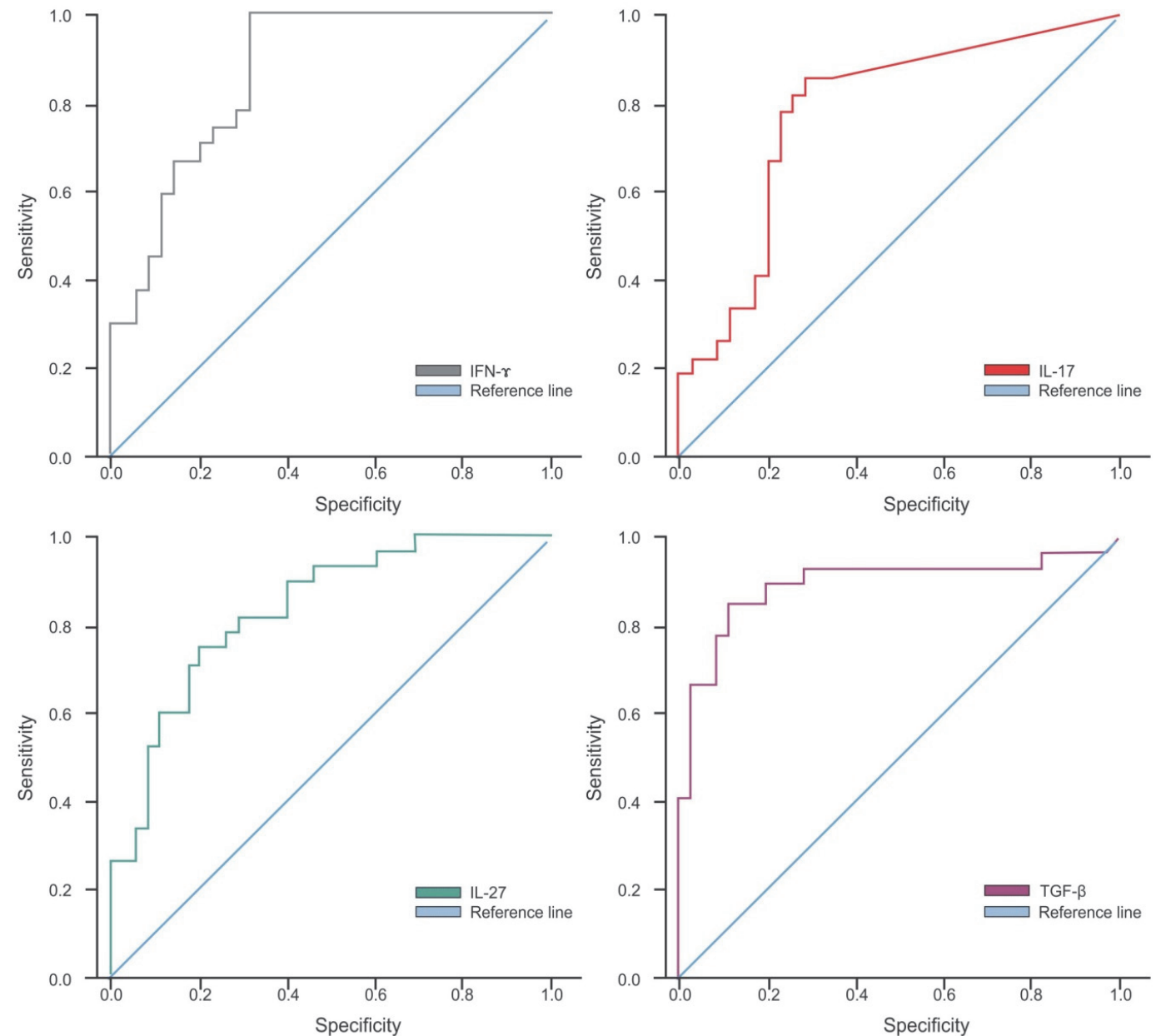

Figure 3. State markers for UC. ROC curves illustrate the specificity and sensitivity of IL-17, IL-27, IFN- $\gamma$ and TGF- $\beta$ serum levels in attempt to differentiate control subject from patients with UC.
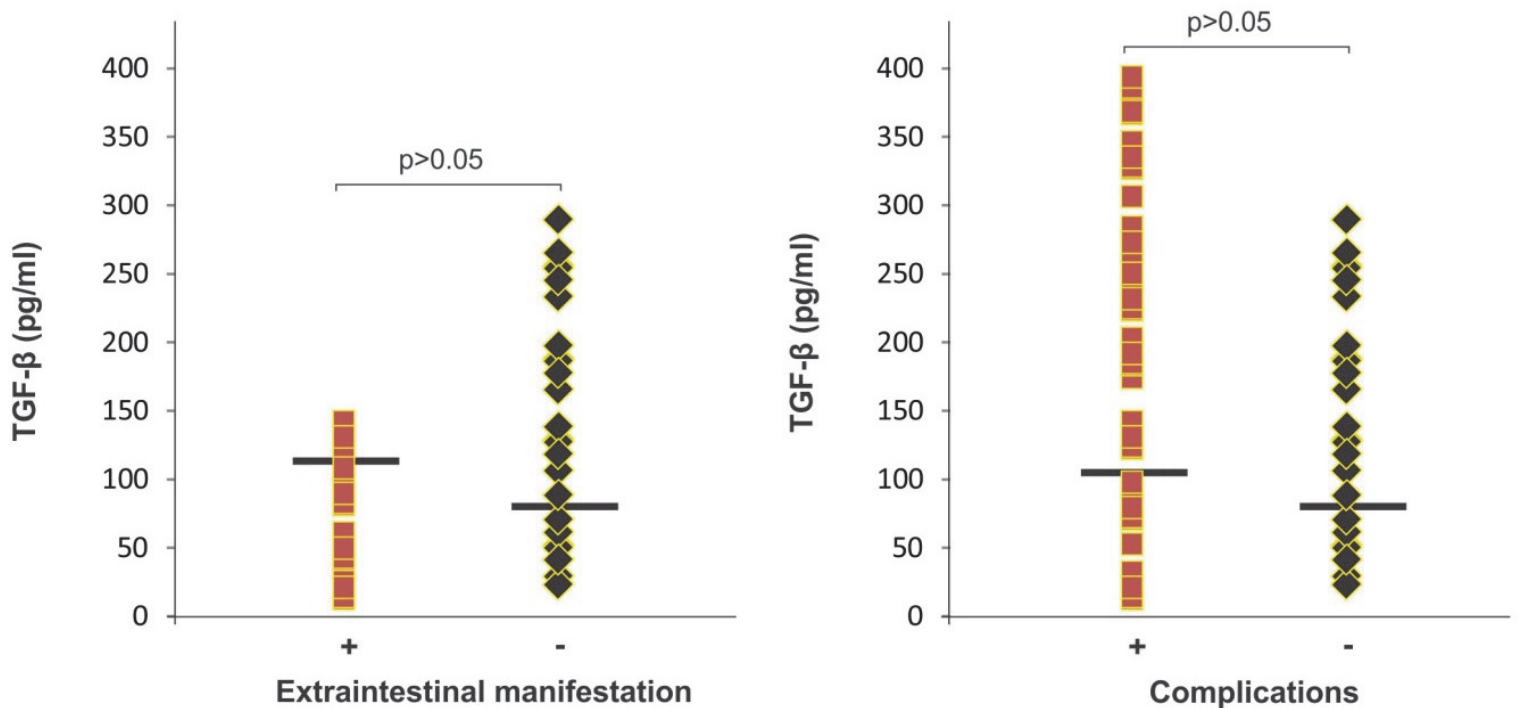

Figure 4. Serum value of TGF- $\beta$ in patients with UC, based on disease severity.

Left panel. Patients with UC were divided in two groups, based on presence of extraintestinal manifestations. Increased concentration of TGF- $\beta$ in UC patients with extraintestinal manifestations. Right panel. Patients with UC were selected in two groups, based on local complications. Increased concentration of TGF- $\beta$ in sera of patients with UC with presence of local complications. Serum levels of cytokine were determined by ELISA. Statistical significance was tested by Mann-Whitney Rank Sum test or independent samples t-test, where appropriate. 
ence of local complications (TGF- $\beta$ : 103,89 (4,39-406,66) vs. $78,08(11,62-323,41) \mathrm{pg} / \mathrm{ml}$; did not reveal statistically significant difference; Figure 4).

\section{DISCUSSION}

In the present study we showed increased systemic values of cytokines IL-17, IL-27, IFN- $\gamma$ and TGF- $\beta$ in patients with UC in comparison to healthy controls (Figure 1). Patients with UC had significantly higher IL-27/IL-17, IFN- $\gamma /$ TGF- $\beta$ and IL-17/TGF- $\beta$ ratios compared to healthy volunteers (Figure 2). Furthermore, the serum values of TGF- $\beta$ higher than $20 \mathrm{pg} / \mathrm{ml}$ present a highly sensitive and specific marker for UC (Figure 3).

We found significant elevation in levels of IL-17, IL27 , IFN- $\gamma$ and TGF- $\beta$ in patients with UC in comparison to healthy volunteers, indicating on robust immune response (Figure 1). Previous studies revealed strong positive correlation between increased synthesis of IFN- $\gamma$ and disease severity, in UC patients (32). The number of lamina propria IFN- $\gamma$ positive cells was increased in UC patients compared with controls, but not as remarkably as in CD (33). Increment of IL-17 leads to the induction of many pro-inflammatory mediators, such as TNF- $\alpha$, IL-6, IL-1 $\beta$ and IFN- $\gamma$, indicating on important role of IL-17 in facilitating inflammation (34-36). Although several studies point on protective role of IL-17, by inhibiting Th1 polarization and subsequent IFN- $\gamma$ dependent inflammation, majority lines of evidence suggest that IL-17 contribute to intestinal inflammation (34-37). IL-27 mediated Th1 polarization and IFN- $\gamma$ production in naive $\mathrm{CD}^{+} \mathrm{T}$ cells, acting in cooperation with other pro-inflammatory cytokines $(38,39)$. The fact that both cytokines share STAT1 signaling pathway explains functional overlaps between IL-27 and IFN- $\gamma(38,39)$. TGF- $\beta$, as an inhibitory cytokine, represents a key regulator of immunological homeostasis and inflammation in UC (40-42). While reduced TGF- $\beta$ activity is considered to be responsible for the development of autoimmune disorders including UC, increased TGF- $\beta$ is considered as compensatory mechanism by promoting potent immunosuppressive effect (40-42). Increment of systemic IL-17, IL-27 and IFN- $\gamma$ induce differentiation and stabilization of polarized Th1 immune response, which is hallmark of Crohn`s disease (1). In majority of studies, in $\mathrm{UC}$, the local immune response is less Th1 polarized. Consistent with these data, the cytokines driving UC were identified with Th2-like characteristics (1). More recently, several studies have shown that levels of proinflammatory cytokines including IL-17 were increased in $\mathrm{UC}(1,43)$. Still, this increment was found to be far less than in CD $(1,43)$.

In line with previous finding, we revealed higher IL-27/IL-17, IFN- $\gamma /$ TGF- $\beta$ and IL-17/TGF- $\beta$ ratios in patients with UC (Figure 2). These finding proves that disease progression correlates with pro-inflammatory immune response, developing toward Th1/Th17 direction. In addition, IFN- $\gamma /$ TGF- $\beta$ and IL-17/TGF- $\beta$ ratios are less than 1 (0,82 and 0,47; respectively; Figure 2$)$, indicating on predominance of immunosuppressive TGF- $\beta$ above pro-inflammatory IFN- $\gamma$ and IL-17 in patients with UC. Our results implicate robust immunosupressive response through TGF- $\beta$ production, in patients with UC. TGF- $\beta$ concentration in serum of UC patients was elevated, comparing to healthy controls. In line with our results, it was previously noticed that TGF- $\beta$ serum level was significantly increased in patients with UC, compared with control subjects (40-42). The main sources of TGF- $\beta$ are mieloid derived supressor cells (MDSCs) and regulatory $\mathrm{T}$ cells (Tregs), and it has been noticed that patients with UC display higher number of MDSCs and Tregs in local tissue $(44,45)$. They are largely responsible for inhibiting host T-cell activity, however, the roles of MDSCs and Tregs in UC are not yet well understood, and there are controversies regarding their immunosuppressive functions $(44,45)$.

We also envisage the possible role of IL-17, IL-27, IFN- $\gamma$ and TGF- $\beta$ as biomarkers of UC. According to our results, TGF- $\beta$ could be a valuable marker for distinguishing patients with UC from healthy controls, since the level of TGF- $\beta$ enhanced the risk for UC (Figure 3 ). We found that optimal cutoff value estimated for TGF- $\beta$ that allows discrimination form a healthy patients was $20 \mathrm{pg} / \mathrm{ml}$, with $85,2 \%$ sensitivity and $88,6 \%$ specificity.

The role of TGF- $\beta$ in UC varies by cell type but also by stage of disease. We analyzed serum level of TGF- $\beta$ in groups of patients with UC categorized on disease severity: extraintestinal manifestations and local complications (29-31). Serum concentration of TGF- $\beta$ was increased in patients with severe UC, although this difference did not reach statistical significance (Figure 4). Our previous findings suggest that in UC patients, enhanced systemic pro-inflammatory immune response correlates with disease severity (46). Taken together, during disease progression, robust tissue destruction is associated with strong pro-inflammatory immune response, and increased TGF- $\beta$ production could be compensatory feedback mechanism.

In conclusion, our data revealed increased systemic values of cytokines IL-17, IL-27, IFN- $\gamma$ and TGF- $\beta$ as well as higher IL-27/IL-17, IFN- $\gamma /$ TGF- $\beta$ and IL-17/TGF- $\beta$ ratios in patients with $\mathrm{UC}$ in comparison to healthy controls. We believe that enhanced production of pro-inflammatory cytokines IL-17, IL-27, IFN- $\gamma$ could further facilitate disease progression. In addition, IFN- $\gamma /$ TGF- $\beta$ and IL-17/ TGF- $\beta$ ratios less than 1 indicate on predominance of immunosuppressive TGF- $\beta$ in patients with UC. This may be way to counteract or limit ongoing pro-inflammatory processes and prevent further tissue destruction. Furthermore, the serum values of TGF- $\beta$ can be used as a valuable marker for UC.

We thank Aleksandar Ilic, Branislav Stevanovic and Milan Milojevic for excellent technical assistance. This work 
was supported by Serbian Ministry of Science and Technological Development (Grants OP 175071, OP 175103 and OP 175069) and by the Faculty of Medical Sciences, University of Kragujevac, Serbia (Grants JP 04/15 and JP 06/15).

\section{REFERENCES}

1. Sanchez-Munoz F, Dominguez-Lopez A, YamamotoFurusho JK. Role of cytokines in inflammatory bowel disease. World J Gastroenterol. 2008; 14: 4280-8.

2. Bamias G, Kaltsa G, Ladas SD. Cytokines in the pathogenesis of ulcerative colitis. Discov Med. 2011; 11: 459-67.

3. Mager LF, Wasmer M-HC, Rau TT, Krebs P. Cytokineinduced Modulation of Colorectal Cancer. Front Oncol 2016; 6: 1-19.

4. Landskron G, De La Fuente M, Thuwajit P, Thuwajit C, Hermoso MA. Chronic inflammation and cytokines in the tumor microenvironment. J Immunol Res 2014; 2014. doi:10.1155/2014/149185.

5. Gattoni A, Parlato A, Vangieri B, Bresciani M, Derna R. Interferon-gamma: biologic functions and HCV therapy (type I/II) (1 of 2 parts). Clin Ter. 2006; 157: 377-86.

6. Schroder K, Hertzog PJ, Ravasi T, Hume DA. Interferon-gamma: an overview of signals, mechanisms and functions. J Leukoc Biol. 2004; 75: 163-89.

7. Cua DJ, Tato CM. Innate IL-17-producing cells: the sentinels of the immune system. Nat Rev Immunol. 2010; 10: 479-489.

8. Sutton CE, Lalor SJ, Sweeney CM, Brereton CF, Lavelle EC, Mills KH. Interleukin-1 and IL-23 induce innate IL-17 production from gammadelta $\mathrm{T}$ cells, amplifying Th17 responses and autoimmunity. Immunity. 2009; 31: 331-341.

9. Martin B, Hirota K, Cua DJ, Stockinger B, Veldhoen $M$. Interleukin-17-producing gammadelta $T$ cells selectively expand in response to pathogen products and environmental signals. Immunity. 2009; 31: 321-330.

10. Ouyang W, Kolls JK, Zheng Y. The biological functions of $\mathrm{T}$ helper 17 cell effector cytokines in inflammation. Immunity. 2008; 28: 454-467.

11. Milner JD. IL-17 producing cells in host defense and atopy. Curr Opin Immunol. 2011; 23: 784-788.

12. Kuchroo VK, Ohashi PS, Sartor RB, Vinuesa CG. Dysregulation of immune homeostasis in autoimmune diseases. Nat Med. 2012; 18: 42-47.

13. Ahmed M, Gaffen SL. IL-17 in obesity and adipogenesis. Cytokine Growth Factor Rev. 2010; 21: 449-453.

14. Trinchieri G. Cancer and inflammation: an old intuition with rapidly evolving new concepts. Annu Rev Immunol. 2012; 30: 677-706.

15. Gallimore AM, Godkin A. Epithelial barriers, microbiota, and colorectal cancer. N Engl J Med. 2013; 368: 282-284.

16. Ye P, Rodriguez FH, Kanaly S, Stocking KL, Schurr J, Schwarzenberger P, et al. Requirement of interleukin 17 receptor signaling for lung CXC chemokine and granulocyte colony-stimulating factor expression, neutrophil recruitment, and host defense. J Exp Med. 2001; 194: 519-527.
17. Chung DR, Kasper DL, Panzo RJ, Chitnis T, Grusby MJ, Sayegh MH, et al. CD4+ T cells mediate abscess formation in intra-abdominal sepsis by an IL-17-dependent mechanism. J Immunol. 2003; 170: 1958-1963.

18. Huang W, Na L, Fidel PL, Schwarzenberger P. Requirement of interleukin-17A for systemic antiCandida albicans host defense in mice. J Infect Dis. 2004; 190: 624-631.

19. Ishigame H, Kakuta S, Nagai T, Kadoki M, Nambu A, Komiyama Y, et al. Differential roles of interleukin-17A and $-17 \mathrm{~F}$ in host defense against mucoepithelial bacterial infection and allergic responses. Immunity. 2009; 30: 108-119.

20. G. Trinchieri, S. Pflanz, and R. A. Kastelein. The IL-12 family of heterodimeric cytokines: new players in the regulation of T cell responses. Immunity. 2003;19: 641-644

21. D. A. A. Vignali and V. K. Kuchroo. IL-12 family cytokines: immunological playmakers. Nature Immunology 2012;13: 722-728.

22. Molle C, Nguyen M, Flamand V, Renneson J, Trottein F, De Wit D, Willems F, Goldman M, Goriely S.. IL-27 synthesis induced by TLR ligation critically depends on IFN regulatory factor 3 . The Journal of Immunology 2007; 178: 7607- 7615 .

23. N. D. Pennock, L. Gapin, and R. M. Kedl. IL-27 is required for shaping the magnitude, affinity distribution, and memory of $\mathrm{T}$ cells responding to subunit immunization. PNAS 2014; 111: 16472-16477.

24. H. Yoshida and C. A. Hunter. The immunobiology of interleukin-27. Annual Review of Immunology 2015; 33: 417-443.

25. S. Aparicio-Siegmund and C. Garbers. The biology of interleukin-27 reveals unique pro- and anti-inflammatory functions in immunity. Cytokine and Growth Factor Reviews 2015; 26: 579-586.

26. Liu C, Zhang L, Chang X, Cheng Y, Cheng H, Ye X, et al. Overexpression and immunosuppressive functions of transforming growth factor 1 , vascular endothelial growth factor and interleukin-10 in epithelial ovarian cancer. Chinese J Cancer Res 2012; 24: 130-7.

27. Neuzillet C, Tijeras-Raballand A, Cohen R, Cros J, Faivre S, Raymond E, et al. Targeting the TGF?? pathway for cancer therapy. Pharmacol Ther 2015; 147: 22-31.

28. Jovanovic I, Radosavljevic G, Pavlovic S, Zdravkovic N, Martinova K, Knezevic M, Zivic D et al., Th-17 cells as novel participant in immunity to breast cancer. Serb. J. Exp. Clin. Res. 2010. 11: 59-6.

29. Jonathan S. Levine, and Robert Burakoff. Extraintestinal manifestations of inflammatory bowel disese. Gastroenterology and hepatlogy. 2011; 7: 235-41.

30. De Dombal FT, Watts JM, Watkinson G, Goligher JC. Local Complications of Ulcerative Colitis: Stricture, Pseudopolyposis, and Carcinoma of Colon and Rectum. British medical journal. 1966; 1: 1442-7.

31. Lashner BA, Turner BC, Bostwick DG, Frank PH, Hanauer SB. Dysplasia and cancer complicating strictures in ulcerative colitis. Digestiv disease and Sciences. 1990; 35(3): 349-352. 
32. Bamias G, Martin C 3rd, Marini M, Hoang S, Mishina M, Ross WG, Sachedina MA, Friel CM, Mize J, Bickston SJ, Pizarro TT, Wei P, Cominelli F. Expression, localization, and functional activity of TL1A, a novel Th1-polarizing cytokine in inflammatory bowel disease. J Immunol 2003; 171: 4868-4874.

33. Camoglio L, Te Velde AA, Tigges AJ, Das PK, Van Deventer SJ. Altered expression of interferon-gamma and interleukin-4 in inflammatory bowel disease. Inflamm Bowel Dis. 1998; 4: 285-90.

34. Langrish CL, Chen Y, Blumenschein WM, Mattson J, Basham B, Sedgwick JD, McClanahan T, Kastelein RA, Cua DJ. IL-23 drives a pathogenic $T$ cell population that induces autoimmune inflammation. J Exp Med 2005; 201: 233-240.

35. Park H, Li Z, Yang XO, Chang SH, Nurieva R, Wang YH, Wang Y, Hood L, Zhu Z, Tian Q, Dong C. A distinct lineage of CD4 T cells regulates tissue inflammation by producing interleukin 17 . Nat Immunol 2005; 6: 1133-1141.

36. Ruddy MJ, Wong GC, Liu XK, Yamamoto H, Kasayama S, Kirkwood KL, Gaffen SL. Functional cooperation between interleukin-17 and tumor necrosis factor-alpha is mediated by CCAAT/enhancer-binding protein family members. J Biol Chem 2004; 279: 2559-2567.

37. O'Connor W Jr, Kamanaka M, Booth CJ, Town T, Nakae S, Iwakura Y, et al. A protective function for interleukin 17A in $\mathrm{T}$ cell-mediated intestinal inflammation. Nat Immunol. 2009; 10(6):603-609.

38. S. Pflanz, J. C. Timans, J. Cheung et al. IL-27, a heterodimeric cytokine composed of EBI3 and p28 protein, induces proliferation of naive CD4+ T cells. Immunity 2002; 16: 779-790.
39. S. Lucas, N. Ghilardi, J. Li, and F. J. De Sauvage. IL-27 regulates IL-12 responsiveness of na"1ve CD4+ T cells through Stat1- dependent and -independent mechanisms. PNAS 2003; 100: 15047-15052.

40. Marek A, Brodzicki J, Liberek A, Korzon M. TGF-beta (transforming growth factor-beta) in chronic inflammatory conditions - a new diagnostic and prognostic marker? Med Sci Monit 2002; 8: RA145-RA151.

41. Monteleone G, Kumberova A, Croft NM, McKenzie C, Steer HW, MacDonald TT. Blocking Smad7 restores TGFbeta1 signaling in chronic inflammatory bowel disease. J Clin Invest 2001; 108: 601-609.

42. Del Zotto B, Mumolo G, Pronio AM, Montesani C, Tersigni R, Boirivant M. TGF-beta1 production in inflammatory bowel disease: differing production patterns in Crohn's disease and ulcerative colitis. Clin Exp Immunol 2003; 134: 120-126.

43. Chunfang Gu, Ling Wu and Xiaoxia Li. IL-17 family: cytokines, receptors and signaling. Cytokine. 2013; 64: doi:10.1016/j.cyto.2013.07.022.

44. Yeon-Jeong Kim, Sun-Young Chang and Hyun-Jeong. Myeloid-Derived Suppressor Cells in Inflammatory Bowel Disease. Intest Res. 2015; 13: 105-111.

45. Györgyi Műzes, Béla Molnár, and Ferenc Sipos. Regulatory $\mathrm{T}$ cells in inflammatory bowel diseases and colorectal cancer. World J Gastroenterol. 2012; 18: 5688-5694.

46. ND Zdravkovic, IP Jovanovic, GD Radosavljevic, AN Arsenijevic, ND Zdravkovic, SLj Mitrovic, NN Arsenijevic. Potential Dual Immunomodulatory Role of VEGF in Ulcerative Colitis and Colorectal Carcinoma. Int J Med Sci 2014; 11: 936-947. 